\title{
Phytochemical Constituents of Some Medicinal Plants in South West, Nigeria
}

\author{
Afolabi F, And Afolabi O.J \\ Applied Sciences Department, Faculty of Science, Osun State Polytechnic, Iree, Osun State, Nigeria.
}

\begin{abstract}
The present study was undertaken to investigate the phytochemical constituents of leaves of four medicinal plants viz: Annona senegalensis, Axonopus compressus, Bryophyllum pinnatum and Heliotropium indicum, which are traditionally used as medicine in southwestern part of Nigeria. Qualitative analysis carried out on each plant leaves shows that alkaloids, phenolics, flavonoids, saponins, tannins, were present in all the plants. These plants leaves were also subjected to quantitative analysis and the results indicated that Alkaloids and phenolics distribution were highest in Annona senegalensis followed by Heliotropium indicum while Bryophylum pinatum has the lowest distribution. Flavonoids distribution was highest in Boyophyllum pinnatum followed by Annona senegalensis while Axonopus compressus has the least distribution. Saponins was highest in Heliotropium indicum followed by Bryophyllum pinnatum while axonopus compressus has the least. Tannins distribution was highest in Heliotropium indicum followed by annona senegalensis and Axonopus compressus while Bryophylum pinnatum has the least.
\end{abstract}

\section{Introduction}

The world is blessed with natural and unique medicinal plants [9]. A medicinal plant is any plant, which in one or more of its organs contains active ingredients which can be used for therapeutic purposes or contain foundation compounds that can be used for the synthesis of useful drugs. Medicinal plants have invariably been a rich source of new drugs and many drugs in use today were either obtained from plants or developed using their chemical structure as templates [2]. The medicinal value of these plants lies in bioactives phytochemical constituents that produce definite physiological action on the human body [3].

Phytoconstituents are the natural bioactive compounds present in plants which combined with nutrients and fibers to form an integrated part of human defence mechanisms against diseases and stress conditions [8]. Phytochemicals are basically divided into two groups that is primary and secondary constituents according to their function in the plant metabolism. Primary constituents comprises common sugars, amino acids, proteins and chlorophyll while secondary constituents consists of alkaloids, flavonoids, phenolics, saponins and so on [5]. The important values of some plants have long been published but a large number of them remain unexplored as yet. So there is a necessity to explore their uses and to conduct pharmacognostic and pharmacological studies to ascertain their therapeutic properties [11].

Annona senegalensis, axonopus compressus, Bryophyllum pinnatum and Heliotropium indicum were chosen to study because they were some of the traditionally used medicinal plants in the southwestern past of Nigeria for the treatment of inflammation and cancer. The present study aims at drawing attention to the phytochemical constituents of these plants and comparing them with a view to providing useful information towards effective utilization of these plants. And also bring into focus the scientific rationale behind the usage of these plants in traditional medicine.

Collections of plant samples.

\section{Materials And Methods}

The medicinal plant Species Annona Senegalensis, Axonopus Compressus and Bryophyllum Pinnatum were collected from Iree, Osun state while Heliotropium indicum was collected from Ikirun, Osun State Nigeria. These plants were identified at the Herbarium section of the Obafemi Awolowo University, Ile-Ife Osun State Nigeria. Leaves of these plants were processed and analyzed.

\section{Processing of plants samples}

The leaves of the plants were air-dried for about 2 weeks and then pulverized using a mechanical grinder. $20 \mathrm{~g}$ of each sample were weighed and soaked in $100 \mathrm{ml}$ of methanol at room temperature for $72 \mathrm{hrs}$ under regular shaking. Extract of each sample was then filtered using Whatman filter paper. The filtrates were evaporated to dryness using evaporating dish at $35^{\circ} \mathrm{C}$. qualitative and quantitative phytochemical analysis were conducted on each sample using standard methods [7]. These tests were based on the visual observation of colour modification, or precipitate formation after the addition of specific reagents. 


\section{Qualitative analysis}

\section{Results}

Qualitative analysis carried out on each plant leaves sample showed the presence of pyhtochemical constituents and the results are summarized in Table 1. It shows that alkaloids, phenolics, flavonoids, Saponins and tannins were present in all plants under investigation.

\section{Plants}

Saponins

Annona senegalensis $++$

Axonopus compressus

$++$

Bryophylum Pinnatum $++$

Heliotropium Indicum $++$

Table 1: Qualitative analysis on phytochemical constituents

$\begin{array}{ccc}\begin{array}{c}\text { Alkaloids } \\ \text { Tannins }\end{array} & \text { Phenolics } & \text { Flavonoids } \\ +++ & +++ & ++ \\ ++ & & + \\ + & ++ & ++ \\ + & + & ++ \\ + & & + \\ ++ & ++ & \end{array}$

Key:

High presence of pyhtochemical constituents: $\quad+++$

Moderate presence of pyhtochemical constituents: $\quad++$

Low presence of phytochemical constituents: +

Absences of pytochemical constituents:

Table 2: Quantitative Analysis of pyhtochemical constituents (mg/100g)

Plants

Saponins

Annona senegalensis

$431.67 \pm 25.10$

Axonopus compressus

$175.00 \pm 0.20$

Bryophylum Pinnatum

$458.20 \pm 12.58$

Heliotropium Indicum

$518.46 \pm 0.25$

\section{Alkaloids Phenolics}

Tannins

$966.67 \pm 15.30$

$85.67 \pm 2.50$

$326.67 \pm 0.12$

$66.67 \pm 0.11$

$243.30 \pm 6.70$

$53.60 \pm 5.16$

$860.00 \pm 0.12$

$112.30 \pm 0.17$
$62.60 \pm 0.60$

$35.16 \pm 0.16$

$12.40 \pm 0.40$

$53.67 \pm 0.20$
Flavonoids

$536.67 \pm 25.10$

$216.20 \pm 0.19$

$873.3 \pm 20.80$

$246.67 \pm 0.16$

Values are mean of triplicate determinations \pm standard deviation

The results of quantitative analysis on five major groups of pyhtochemical constituents of leaves of four medicinal plants investigated were summarized and shown in Table 2. Annona Senegalesis has the highest yield of alkaloid and phenolics which are $966.67 \pm 15.30$ and $62.6 \pm 0.60$ followed by Heliotropium indicum which are 860.0 \pm 0.12 and $53.67 \pm 0.20$ respectively and Axonopus compressus contained $326.67 \pm 0.122$ and $35.16 \pm 0.16$ while Bryophylum pinnatum has the lowest yield of alkaloids and phenolics with the values of $243.30 \pm 0.40$ respectively.

From the results shown in Table 2, Bryophylum Pinnatum has the highest values of flavonoids which is $873.3 \pm 20.80$ followed by Annona senegalensis which is $536.67 \pm 25.10$. Heliotropium indicum has the value of $246.67 \pm 0.16$ while Axonopus compressus has the least value which is $216.20 \pm 0.19$.

However, Heliotropium indicum has the highest values of saponins with the values of $518.46 \pm 0.75$ followed by Bryophyllum pinnatum with the values of $458.20 \pm 12.58$. Annona senegalensis has the value of $431.67 \pm 25.10$ while Axonopus compressus has the lowest yield with the values of $175.00 \pm 0.20$. In respect of

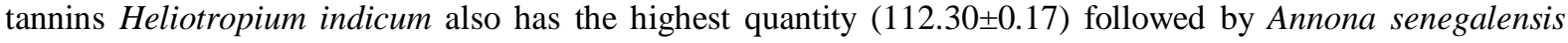
(85.67 \pm 2.50$)$. Axonopus compressus has tannins yield of $66.67 \pm 0.11$ while Bryophyllum pinnatum has the lowest quantity of tannins with the values of $53.60 \pm 5.16$.

\section{Discussion}

Phytochemical analysis of the samples of four medicinal plants under investigation revealed the presence of tannins, Saponins, flavonoids, phenolics and alkaloids in their leaves. This is in tandem with the report of Stauth [13], who also detected the presence of saponins, tannins and alkaloids in the methanol leaf extract of these plants. Flavonoids and sugars derived from selected medicinal plants from some parts of the world, were shown to exhibit antidiarrhoeal properties [4]. Reports by different authors, [1; 10; 14]. Have shown 
that the active ingredients in a number of medicinal plants which enable them to exhibit antibiotic properties were due to alkaloids, flavonoids, tannins, saponins and reducing sugars present in them.

The presence of alkaloids, saponins, phenolics, flavonoids and tannins explains the reason why the leaves of these medicinal plants are used for the treatment of various diseases. For example, flavonoids are known to act as antioxidant by removing the highly unstable molecules called free radicals which damaged the body cells, thereby contributing to a variety of diseases such as cancer, inflammation, heart diseases and aging [9; 13]. Flavonoids also responsible for the antipyretic (fever-reducing), analygesic (pain-relieving) and spasmolytic (spasm-inhibiting) properties of these plants [9; 12].

According to Dweck and Mitchell [6]. Ayuveda herbal formula called chay avanprasha which is used as a sexual vitality tonic is believed to contain phenolic constituents.

Tannins has high potency for the treatment of intestinal disorders such as diarrhea and dysentery [4; 12]. The presence of alkaloids and saponins explains the reason why these medicinal plants are used to treat hypertension because alkaloids and saponins prevent the excessive intestinal absorption of cholesterol and thus reduce the risk of cardiovascular diseases such as hypertension [4].

\section{Conclusion}

\section{Conclusion And Recommendation}

From the results of our analysis, it is important to note that the medicinal values of these plants lies in bioactive phytochemical constituents which combined with nutrients and fibres to form an integrated part of human defence mechanisms against diseases and stress.

\section{Recommendation}

We hereby recommend that further work should be carried out especially on the dosage/response potency of these medicinal plants.

\section{References}

[1]. Agunu, A., Yusuf S., Andrew G.O., Zezi, A.U and Abdurahman, E.M (2005). Evaluation of Five Medicinal Plants used in Diarrhoea Treatment in Nigeria. Journal of Ethnopharmacology 101, 27 - 30.

[2]. Ajaiyeoba E., Falade M, Ogbole O., Okpako L, and Akinboye D. (2006). In vivo Antimalaria and Cytotoxic Properties of Annona Senegalensis Extract. Afr. J. Trad. CAM 3 (1) : $137-141$.

[3]. Akinmoladun A.C, Ibukun, E.O., Afor E., Obuotor E.M., and Farombi E.O. (2007). Phytochemical Constituents and Antioxidant Activity of Extract from the Leaves of Ocimum Gratissimum. Sc. Res. Essay 2: Pp. $163-166$.

[4]. Akinpelu D.A, and Onakoya, T.M. (2006). Antimicrobial Activities of Medicinal Plants used in Folklore Remedies in SouthWestern. Afri. J. Biotechnol. 5 : $1078-1081$.

[5]. Dhawale P.G. (2013). Phytochemical Analysis of some Medicinal Plants from Yanatmal District (Ms) India. The International Journal of Engineering and Science 2 (1) Pp. $65-66$.

[6]. Dweck A.C, and Mitchell, D. (2002). Emblica Officinalls (syn: phyllanthus Emblica) or Amia: the Ayuruedic wonder. Chesham Chemicals Ltd. London.

[7]. Edeoga H.O., Okwu, D.E and Mbaebie B.O. (2005). Phytochemical Constituents of some Nigerian Medicinal Plants. Afri. J. Biotechnol 4 (7) : Pp. $685-688$.

[8]. Khandare, N.A (2012). Qualitative Poytopchemical Analysis of Ethanomedicinally Important Plant Cappairis Aphyla Roth (Capparidaceae) from Akola Distric, Maharashtra, India. IRJP 3(4) pp 206 - 207.

[9]. Krishnaiah D., Devi T. Bomo A and Sarbatly R. (2009). Studies on Phytochemical Constituents of Six Malaysian Medicinal Plants. Journal of Medicinal Plants. Journal of Medicinal Plants Research Vol. 3 (2) Pp. 067 - 072.

[10]. Longanga Otshudi, A., Vercruysse A., Forlers A. (2000). Contribution to the Ethinobotanical Phytochemical and Pharmacological Studies of Traditionally used Medicinal Plants in the Treatment of Dyseutery and Diarrhea in Lomela Area, Democratic Republic of Congo (DRC) Journal of Ethnopharmacology 71, $411-423$.

[11]. Mustaq A.Q, Rahmatullah, A. Muhammad A.K Mirand and Muhammad Z. (2009). Traditional Herbal Remedies used for the Treatment of Diabetes from District Attock (Pakistan) Pak. J. Bot., 41 (6) : 2777 - 2782.

[12]. Olaleye M.T (2007). Cytotoxicity and Antibacterial Activity of Methanolic Extract of Hibiscus Sbdariffia. J. Med. Plants Res. 1(1) : $009-013$.

[13]. Stauth D. (2007). Studies Force New View on Biology of Flavonoids. Oregun State University, U.S.A.

[14]. Suleiman M.M, Dzenda T and Sani C.A (2007). Antidiarrheal Activity of the Methanol Stem-nbark Extract of Annona Senegalensis Pers. (Annonaceae) Journal of Ethnopharmacology $116: 25$ - 130. 